\title{
EFEKTIFITAS KOTORAN SAPI SEBAGAI AKTIFATOR PEMBUATAN BIOGAS DARI JERAMI PADI
}

\author{
Nindi Fajri, Haidina Ali, Mualim \\ Politeknik Kesehatan Kementerian Kesehatan Bengkulu, Jurusan Kesehatan Lingkungan, \\ Jalan Indragiri Nomor 03 Padang Harapan Kota Bengkulu \\ ndii.fajri@facebook.com
}

\begin{abstract}
Biogas is gas mixture yielded by bacterium of metanogenik that happened at materials able to ravelled naturally in a condition anaerobik. Target of in this research is known by time depth forming of biogas of paddy hay with ox dirt aktifator. This research is research of eksperiment by using Posttest design group control only design. This research use two data analysis that is Univariat and Bivariate. Pursuant to result of test of anoway anova research of time depth mean forming of biogas with addition of ox dirt 3 singk during 11 day, addition of ox dirt 5 singk during 9 day, and addition of ox dirt 7 time depth mean singk forming of biogas during 8 day, while time depth forming of biogas at control during 17 day with value $p=0,000=0,05$. That there is difference having a meaning of among/between time depth forming of biogas to addition of dirt aktifator with dose of aktifator 3 singk, 5 singk, and 7 singk.
\end{abstract}

Keyword : Hay Paddy, Dirt Ox, Biogas

\begin{abstract}
Abstrak: Biogas adalah campuran gas yang dihasilkan oleh bakteri metanogenik yang terjadi pada material-material yang dapat terurai secara alami dalam kondisi anaerobik. Tujuan dalam penelitian ini adalah diketahui lama waktu terbentuknya biogas dari jerami padi dengan aktifator kotoran sapi. Penelitian ini adalah penelitian eksperiment dengan menggunakan design Posttest only control group design. Penelitian ini menggunakan dua analisis data yaitu Univariat dan Bivariat. Rata-rata lama waktu terbentuknya biogas dengan penambahan kotoran sapi $3 \mathrm{~kg}$ selama 11 hari, penambahan kotoran sapi $5 \mathrm{~kg}$ selama 9 hari, dan penambahan kotoran sapi $7 \mathrm{~kg}$ selama 8 hari, pada kontrol selama 17 hari dengan $p$ value $=0,000<\alpha=0,05$. Bahwa ada perbedaan yang bermakna antara lama waktu terbentuknya biogas terhadap penambahan aktifator kotoran dengan dosis aktifator $3 \mathrm{~kg}, 5 \mathrm{~kg}$, dan $7 \mathrm{~kg}$.
\end{abstract}

Kata Kunci : Jerami Padi, Kotoran Sapi, Biogas

Berbagai bentuk energi telah digunakan manusia seperti batu bara, minyak bumi, dan gas alam. Energi tersebut digunakan untuk keperluan rumah tangga seperti memasak, penerangan, dan kepentingan yang lebih besar seperti industri serta pengolahan hasil pertanian. Kelangkaan bahan bakar mengakibatkan meningkatnya harga bahan bakar minyak (BBM) sebagai sumber energi fosil yang tidak dapat diperbaharui (unrenewable). Sedangkan permintaan akan bahan bakar fosil terus mengalami kenaikan. Salah satu jalan untuk menghemat BBM adalah mencari sumber energi alternatif yang dapat diperbaharui (renewable). Sebetulnya sumber energi alternatif cukup tersedia, misalnya energi matahari di musim kemarau atau mu- sim kering, energi angin, dan air. Tenaga air memang paling banyak dimanfaatkan dalam bentuk Pembangkit Listrik Tenaga Air (PLTA), namun sumber energi lain belum kelihatan secara signifikan. Salah satu limbah hasil pertanian yang paling banyak tersedia adalah jerami padi. Kebanyakan jerami padi dibakar atau dibuang oleh petani sehingga dapat mencemari lingkungan. Jerami padi dapat dimanfaatkan sebagai bahan campuran pembuatan biogas yang dicampurkan kedalam kotoran ternak karena jerami padi mengandung rasio $\mathrm{C} / \mathrm{N}$ yang tinggi.

Kandungan biogas didominasi oleh gas metan $\left(\mathrm{CH}_{2}\right)$ yang merupakan hasil sampingan dari proses dekomposisi mikroba hasil fermentasi. Mikroba tersebut merupakan 
bakteri pembentuk metana yang banyak terdapat dalam tubuh hewan ruminansia seperti kerbau, sapi, domba, kambing, dll. Secara prinsip pembuatan biogas sangat sederhana, dengan memasukkan substrat (kotoran hewan atau manusia) ke dalam unit pencerna (digester), ditutup rapat dan selama beberapa waktu biogas akan terbentuk dan selanjutnya dapat digunakan sebagai sumber energi, selain itu juga dapat membantu pengembangan sistem pertanian dengan mendaur ulang kotoran hewan maupun limbah hasil pertanian untuk memproduksi biogas sebagai bahan bakar, selain itu juga diperoleh hasil sampingan berupa pupuk organik dengan mutu yang baik.

Berdasarkan uraian diatas, maka tujuan yang ingin dicapai dalam penelitian ini adalah diketahui lama waktu terbentuknya biogas dari jerami padi dengan penambahan aktifator kotoran sapi sebanyak $3 \mathrm{~kg}, 5 \mathrm{~kg}$, dan $7 \mathrm{~kg}$, diketahui efektifitas kotoran sapi dalam proses pembentukan biogas dari jerami padi. Diketahui perbedaan lama waktu terbentuknya biogas dari jerami padi dengan dosis aktifator kotoran sapi $3 \mathrm{~kg}, 5 \mathrm{~kg}$, dan 7 $\mathrm{kg}$.

\section{BAHAN DAN CARA KERJA}

Penelitian ini adalah penelitian dengan menggunakan design Post test only control group design. Perlakuan yang terdiri dari 3 perlakuan dan 1 kontrol, dengan perlakuan pertama menggunakan inokulan (biostarter) kotoran sapi sebanyak $3 \mathrm{~kg}+16$ liter air dan bahan dasar jerami padi sebanyak $2 \mathrm{~kg}$. Terbentuknya gas selama 5 hari dan untuk biogas menghasilkan nyala api \pm 10 hari. Perlakuan kedua menggunakan inokulan (biostarter) kotoran sapi sebanyak $5 \mathrm{~kg}+$ air 16 liter dan bahan dasar jerami padi sebanyak $2 \mathrm{~kg}$, terbentuknya gas 3 hari dan untuk biogas dapat menghasilkan nyala api 8 hari. Perlakuan ketiga menggunakan inokulan (biostarter) kotoran sapi sebanyak $7 \mathrm{~kg}+$ air 16 liter dan bahan dasar jerami padi sebanyak $2 \mathrm{~kg}$, terbentuknya gas 3 hari dan untuk biogas menghasilkan nyala api 8 hari. Untuk kontrol bahan dasar jerami padi $2 \mathrm{~kg}$ dan 16 liter air waktu terbentuknya gas yaitu
17 hari dan tidak menghasilkan biogas yang bisa menghasilkan nyala api.

Analisis data dilakukan secara deskriptif yang disajikan dalam bentuk tabel dan analisis bivariat untuk melihat pengaruh yang paling efektif dalam proses pembentuk biogas.

\section{HASIL}

Data yang diperoleh dari hasil penelitian menggunakan kotoran sapi sebagai aktifator dalam proses pembuatan biogas dengan bahan dasar jerami padi adalah lama waktu terbentuknya biogas. Lama waktu terbentuknya biogas dapat ditentukan melalui pengamatan terhadap gas yang terkumpul pada alat penampung gas dengan percobaan uji nyala.

Tabel dibawah ini menunjukkan bahwa rata-rata lama waktu terbentuknya biogas pada kelompok perlakuan dengan penambahan kotoran sapi $7 \mathrm{~kg}$ selama 8 hari dengan $\rho$ value $0,000<0,05$, yang berarti ada pengaruh antara pemberian kotoran sapi sebagai aktifator terhadap pembentuk biogas dengan bahan dasar jerami padi. Hasil uji One way Anova menunjukkan bahwa dengan penambahan $7 \mathrm{~kg}$ kotoran sapi sebagai inokulan mampu menghasilkan biogas lebih cepat dengan rerata lama waktu terbentuknya gas metan yaitu selama 8,33 hari dengan $\rho$ value $0,000<0,05$ sehingga dapat disimpulkan bahwa ada perbedaan yang bermakna dari masing-masing perlakuan.

Untuk mengetahui rerata perbedaan lama waktu terbentuknya biogas dari keempat variabel tersebut yakni penambahan kotoran sapi $3 \mathrm{~kg}, 5 \mathrm{~kg}, 7 \mathrm{~kg}$, dan kontrol maka dilakukan uji LSD (Least Significance Difference) yang menunjukkan bahwa selisih terkecil lama waktu terbentuknya biogas terdapat pada penambahan inokulan kotoran sapi $5 \mathrm{~kg}$ dan $7 \mathrm{~kg}$ yaitu 0.667. Sedangkan selisih terbesar lama waktu terbentuknya biogas terdapat pada penambahan inokulan kotoran sapi $7 \mathrm{~kg}$ dan kontrol yaitu 8.667. Dari selisih tersebut didapat $\rho$ value pada penambahan inokulan kotoran sapi $5 \mathrm{~kg}$ dan 7 
kg yaitu 0.419 , ini menyatakan bahwa tidak ada beda dari kelompok perlakuan tersebut.

Tabel.1 Lama Waktu Terbentuknya Biogas

\begin{tabular}{ccccc}
\hline $\begin{array}{c}\text { Pengu- } \\
\text { langan }\end{array}$ & $\begin{array}{c}\text { Waktu Terbentuknya Biogas } \\
\text { Kotoran } \\
\text { sapi 3 } \\
\text { kg }\end{array}$ & $\begin{array}{c}\text { Kotoran } \\
\text { sapi 5 } \\
\text { kg }\end{array}$ & $\begin{array}{c}\text { Kotoran } \\
\text { sapi 7 } \\
\text { kg }\end{array}$ & \\
& 10 & 8 & 8 & 17 \\
\hline 1 & 13 & 10 & 9 & 17 \\
2 & 11 & 9 & 8 & 17 \\
3 & Kontrol \\
Jumlah & 34 hari & 27 hari & 25 hari & 51 hari \\
Rerata & 11 hari & 9 hari & 8 Hari & 17 hari \\
\hline
\end{tabular}

Hasil uji One Way Anova menunjukkan bahwa lama waktu terbentuknya biogas pada kelompok perlakuan penambahan kotoran sapi $7 \mathrm{~kg}$ selama 8,33 hari.

Tabel.2 Hasil Uji One Way Anova Lama Waktu (hari) Terbentuknya Biogas

\begin{tabular}{lcccc}
\hline \multicolumn{1}{c}{$\begin{array}{c}\text { Variabel } \\
\text { Perlakuan }\end{array}$} & Mean & SD & 95\% CI & Pvalue \\
\hline $\begin{array}{l}\text { 3 kg kotoran } \\
\text { Sapi }\end{array}$ & 11,33 & 1,528 & $7,54-15,13$ & 0,000 \\
$\begin{array}{l}\text { 5 kg kotoran } \\
\text { Sapi }\end{array}$ & 9,00 & 1,000 & $6,52-11,48$ & \\
$\begin{array}{l}\text { 7 kg kotoran } \\
\text { Sapi }\end{array}$ & 8,33 & 0,577 & $6,90-9,77$ & \\
Kontrol & 17,00 & 0,000 & $17,00-17,00$ & \\
\hline
\end{tabular}

Hasil analisis uji LSD untuk mengetahui perbedaan ketiga perlakuan penambahan aktifator kotoran sapi dosis $3 \mathrm{~kg}, 5 \mathrm{~kg}, 7 \mathrm{~kg}$, disajikan pada tabel berikut:

Tabel 3. Hasil Uji LSD Perbedaan Lama Waktu (Hari) Terbentuknya Biogas

\begin{tabular}{|c|c|c|c|}
\hline \multicolumn{2}{|c|}{ Perlakuan } & \multirow{2}{*}{$\begin{array}{c}\text { Rata-rata beda (hari) } \\
5.667\end{array}$} & \multirow{2}{*}{$\begin{array}{r}\rho \text { value } \\
.000\end{array}$} \\
\hline & $3 \mathrm{~kg}$ & & \\
\hline \multirow{2}{*}{ Kontrol } & $5 \mathrm{~kg}$ & 8.000 & .000 \\
\hline & $7 \mathrm{~kg}$ & 8.667 & .000 \\
\hline \multirow[t]{2}{*}{$3 \mathrm{~kg}$} & $5 \mathrm{~kg}$ & -2.333 & .017 \\
\hline & $7 \mathrm{~kg}$ & -3.000 & .005 \\
\hline $5 \mathrm{~kg}$ & $7 \mathrm{~kg}$ & -.667 & .419 \\
\hline
\end{tabular}

\section{PEMBAHASAN}

Pembuatan biogas dari jerami padi dengan menggunakan biodigester kotoran sapi dapat mempengaruhi lama waktu terbentuknya biogas. Rerata lama waktu terbentuknya bio-gas yang diperlukan dengan penamahan inokulan kotoran sapi $7 \mathrm{~kg}$ lama waktu terbentuknya biogas dari jerami padi yaitu selama 8 hari. Penambahan kotoran sapi dan air pada bahan dasar jerami padi dengan 3 kali pengulangan dengan lama waktu terbentuknya biogas pada penambahan kotoran sapi $5 \mathrm{~kg}$ dan $7 \mathrm{~kg}$ + air yaitu 8 hari, dan dengan penambahan kotoran sapi $3 \mathrm{~kg}+$ air yaitu 10 hari. Masing-masing perlakuan dilakukan pengadukan dan pembuangan gas selama 7 hari sampai terbentuknya biogas yang ditandai dengan plastik penampung gas menggembung, dan untuk membuktikan bahwa gas yang terbentuk merupakan gas metan yaitu dengan uji nyala gas yang ada pada plastik penampung gas tersebut.

Hasil uji nyala diketahui bahwa biogas dengan penambahan kotoran sapi $7 \mathrm{~kg}, 5 \mathrm{~kg}$, $3 \mathrm{~kg}$ dan air biasa yang paling cepat menghasilkan gas adalah dengan penambahan inokulan kotoran sapi $7 \mathrm{~kg}$. Hal ini karena kotoran sapi memiliki kandungan selulosa yang tinggi sehingga nilai kalor yang dihasilkan oleh biogas juga cukup tinggi, yaitu kisaran 4800-6700 kkal/ $/ \mathrm{m}^{3}$ untuk metana murni (100\%) memiliki nilai kalori 8900 $\mathrm{kkal} / \mathrm{m}^{3}$ ( 2006).

Berdasarkan tabel 1 diketahui bahwa rerata lama waktu terbentuknya biogas dari masing-masing perlakuan memiliki lama waktu yang berbeda. Perbedaan lama waktu terbentuknya biogas tersebut karena suhu ruang selama proses penelitian tidak stabil terutama pada malam hari. Perubahan suhu tersebut mengakibatkan perkembangbiakan mikroorganisme dalam mendekomposisi bahan organik terganggu sehingga lama waktu terbentuknya biogas akan bervariasi. Jika suhu stabil maka kemampuan mikroorganisme dalam mendekomposisi bahan organik akan cepat dan biogas juga akan terbentuk dengan cepat, namun jika suhu tidak stabil maka bahan organik dalam digester akan lambat terdekomposisi sehingga biogas yang terbentuk akan lebih lama.

Hasil uji One Way Anova berdasarkan Tabel 2 bahwa rata-rata lama waktu terbentuknya biogas dari jerami padi dengan kelompok perlakuan penambahan kotoran sapi $3 \mathrm{~kg}$ dengan rerata lama waktu terbentuknya 
biogas dari jerami padi selama 11,33 hari dengan standar deviasi 1,528 hari. Pada kelompok eksperimen dengan penambahan kotoran sapi $5 \mathrm{~kg}$ dengan rerata lama waktu terbentuknya biogas dari jerami padi selama 9,00 hari dengan standar deviasi 1,000 hari, sedangkan pada kelompok eksperimen dengan penambahan kotoran sapi $7 \mathrm{~kg}$ dengan rerata lama waktu terbentuknya biogas dari jerami padi selama 8,33 hari dengan standar deviasi 0,577 hari, dan rerata lama waktu terbentuknya biogas pada kelompok kontrol selama 17,00 hari dengan standar deviasi 0,000 .

Berdasarkan uji LSD diketahui bahwa kelompok dengan selisih terkecil dengan rerata lama waktu terbentuknya biogas terdapat pada kelompok dosis $5 \mathrm{~kg}$ dan $7 \mathrm{~kg}$ dengan $\rho$ value 0.419 , ini menyatakan bahwa tidak ada perbedaan dari kelompok perlakuan tersebut. Sedangkan selisih terkecil dengan rerata lama waktu (hari) terbentuknya biogas terdapat pada kelompok perlakuan dengan dosis $7 \mathrm{~kg}$ kotoran sapi dan kontrol yaitu 8.667 hari dengan $\rho$ value 0,000 , hal ini menyatakan bahwa ada perbedaan yang bermakna dari kelompok perlakuan tersebut. Kelompok perlakuan dengan penambahan dosis kotoran sapi $7 \mathrm{~kg}$ merupakan yang paling efektif membentuk biogas dengan lama waktu 8 hari.

Kotoran sapi merupakan limbah peternakan yang paling melimpah di dunia yang sebagian besar terdiri dari unsur selulosa, hemisellulosa, lignin, karbonat organik, nitrogen, fosfor, dan kalium.. Oleh karena itu, pupuk sapi kandang memiliki kandungan selulosa yang tinggi sehingga nilai kalor yang dihasilkan oleh biogas juga cukup tinggi, yaitu kisaran $4800-6700 \mathrm{kkal} / \mathrm{m}^{3}$ untuk metana murni (100\%) memiliki nilai kalori 8900 $\mathrm{kkal} / \mathrm{m}^{3}$.

Bristol Roborties Lab (BRL) dari Univesity of bristol sedang meneliti kotoran sapi dijadikan sebagai sel bahan bakar mikroba atau Microbial fuel cells (MFC), sehingga dapat digunakan sebagai penghasil energi tanpa menyebabkan polusi. Kotoran sapi secara kimia sangat aktif, banyak mengandung nitrogen, urea, klorida, kalium dan bili- rubin sehingga akan menjadi bahan bakar yang sangat baik untuk sel bahan baku mikroba.

Biogas adalah teknologi pembuatan energi dengan memanfaatkan limbah, seperti limbah pertanian, limbah perternakan, dan limbah manusia (Wahyuni, 2011). Manfaat biogas secara umum menurut Said (2010), adalah menghasilkan energi, mengubah limbah organik menjadi pupuk berkualitas, mengurangi kapasitas dan waktu kerja wanita, memperbaiki lingkungan melalui pencegahan kerusakan udara (Wahyuni, 2011), faktor dalam (degister) dan faktor luar yang dapat mempengaruhi pembuatan biogas adalah jenis bahan organik, derajat keasaman, keseimbangan $\mathrm{C} / \mathrm{N}$, suhu, laju penggumpalan, zat toksik, pengadukan, starter, dan waktu resensi.

Penelitian ini juga didukung oleh Hardyanti tahun 2009 yang berjudul pembuatan biogas dari kotoran gajah dan air. Biogas tersebut terbentuk pada hari ke-21 dan dilakukan pengadukan 5 hari sekali, sedangkan penelitian adalah pembuatan biogas dengan menggunakan aktivator kotoran sapi $3 \mathrm{~kg}, 5$ $\mathrm{kg}$, dan $7 \mathrm{~kg}$ + air 16 liter dan bahan dasar jerami padi $2 \mathrm{~kg}$ terhadap lama waktu terbentuknya biogas dengan waktu terbentuknya yang paling efektif adalah dosis aktifator $7 \mathrm{~kg}+16$ liter air dengan lama waktu terbentuknya biogas selama 8 hari.

\section{KESIMPULAN}

Berdasarkan hasil penelitian pembentuk biogas jerami padi dengan aktivator kotoran sapi dapat disimpulkan bahwa lama waktu terbentuknya biogas menggunakan bahan dasar jerami padi dengan inokulan (biostater) kotoran sapi didapatkan rata-rata jerami padi $2 \mathrm{~kg}+$ inokulan (biostater) kotoran sapi $3 \mathrm{~kg}$ + air 16 liter dengan rerata lama waktu terbentuknya biogas selama 11 hari. Rerata jerami padi $2 \mathrm{~kg}+$ inokulan (biostater) kotoran sapi $5 \mathrm{~kg}+$ air 16 liter dengan rerata lama waktu terbentuknya biogas selama 9 hari. Serta rata-rata jerami padi sebanyak 2 kg dengan inokulan (biostater) kotoran sapi 7 $\mathrm{kg}+$ air 16 liter dengan rerata lama waktu terbentuknya biogas selama 8 hari. 
Selain itu, penambahan inokulan (biostarter) kotoran sapi dengan dosis $7 \mathrm{~kg}+$ air 16 liter merupakan yang paling efektif membentuk biogas dengan lama waktu terbentuknya biogas selama 8 hari. Serta ada perbe-

\section{DAFTAR RUJUKAN}

BPTP, 2012. Pemanfaatan Kotoran Sapi Sebagai Bahan Biogas. Diakses dari sulsel.litbang.deptan.go.id/.../index.php//...pema nfaatan-kotoran-sapi-sebagai-bahan-biogas tanggal 19 Februari 2013.

Nugroho, Yulianto, 2011. Pemanfaatan Biogas Sebagai Sumber Energi Alternatif Ramah Lingkungan. Diakses dari uliestranger.blogspot.com/ 2011/ 04/ artikelbiogas.html tanggal 7 Februari 2013.

Para Ahli, 2006. Limbah Kotoran Sapi Sebagai Bahan Biogas. Diakses dari krissmile.blogspot.com/.../biogas-dari-kotoran-sapisapi-ternak-html tanggal 5 Februari 2013.

Said, Syahruddin. 2010. Manfaat Biogas Secara Umum. Diakses dari http://kris- daan yang bermakna pada lama waktu terbentuknya biogas dengan penambahan bahan dasar jerami padi menggunakan inokulan (biostater) kotoran sapi $3 \mathrm{~kg}, 5 \mathrm{~kg}, 7$ $\mathrm{kg}+$ air yaitu selama satu hari.

smile.blogspot.com/2012/07/biogas-darikotoran-sapi-sapi-ter, diunduh tnak.html tanggal 2 Januari 2013.

Suyitno, dkk. 2010. Teknologi Biogas, Pembuatan, Operasional Dan Pemanfaatan. Graha Ilmu : Yogyakarta.

Wahyuni, Sry. 2011. Menghasilkan Biogas Dari Aneka limbah. Jakarta Selatan : PT Agro Media Pustaka.

Wijanarko, Wahyu. 2008. Kriteria Jerami Padi Sebagai Bahan Biogas. Diakses dari permintop.files. $\quad$ wordpress.com/2009/06/ standar- analisa- bisnis-sapil. pdf tanggal 19 Februari 2013. 